\title{
The Changing Representation Interface: Democracy and Direct Contact with Politicians
}

DOI:

10.1080/17448689.2016.1134388

\section{Document Version}

Accepted author manuscript

Link to publication record in Manchester Research Explorer

\section{Citation for published version (APA):}

Southern, R., \& Purdam, K. (2016). The Changing Representation Interface: Democracy and Direct Contact with Politicians. Journal of Civil Society, 12(1), 101-120. https://doi.org/10.1080/17448689.2016.1134388

\section{Published in:}

Journal of Civil Society

\section{Citing this paper}

Please note that where the full-text provided on Manchester Research Explorer is the Author Accepted Manuscript or Proof version this may differ from the final Published version. If citing, it is advised that you check and use the publisher's definitive version.

\section{General rights}

Copyright and moral rights for the publications made accessible in the Research Explorer are retained by the authors and/or other copyright owners and it is a condition of accessing publications that users recognise and abide by the legal requirements associated with these rights.

\section{Takedown policy}

If you believe that this document breaches copyright please refer to the University of Manchester's Takedown Procedures [http://man.ac.uk/04Y6Bo] or contact uml.scholarlycommunications@manchester.ac.uk providing relevant details, so we can investigate your claim.

\section{OPEN ACCESS}




\section{The Changing Representation Interface? Democracy and Direct Contact with Politicians}

Rosalynd Southern and Kingsley Purdam

The Cathie Marsh Institute for Social Research, University of Manchester, Manchester, UK

Draft - forthcoming in the Journal of Civil Society 


\title{
The Changing Representation Interface? Democracy and Direct Contact with Politicians
}

\begin{abstract}
The interface between politicians and the electorate is a vital component of the infrastructure of democracy and politicians now have many more tools available to communicate and engage with the electorate. Direct contact between politicians and the electorate is associated with increased levels of civic engagement. In this article we examine the responsiveness of politicians in the United Kingdom by conducting: (i) an innovative test of responses to an undecided voter's email and (ii) follow-up interviews with electoral candidates. We found that a majority of electoral candidates had an identifiable email address and more than half responded to our undecided voter's email. However, there were considerable differences in the content relevance of the responses. There were also very few follow-up emails or further contact from the electoral candidates, suggesting only limited evidence of an integrated communication strategy. Electoral candidates also expressed concerns about communicating in a way that was 'on record'. The findings provide a unique insight into the dynamics of communication between politicians and the electorate and the changing nature of the representation interface. Whilst the Internet has the scope for more personalized and two-way communication and for electors to hold politicians to account, it seems that politicians are more focused on campaign advantage rather than renewing the representation interface.
\end{abstract}

\section{KEYWORDS}

Accountability, democracy, engagement, representation, responsiveness, political party, transparency, vote

\section{Introduction}

The responsiveness of politicians in terms of being contactable and accountable to the electorate is as a key aspect of effective representation (Pitkin 1967). It is important that politicians engage with the electorate and explain policy positions in order to inform voter choice and also to gain an understanding of citizens' concerns. Communication and dialogue is thought to be one of the ways to address the declining levels of civic engagement, in part because of its link with giving citizens a sense of efficacy and building trust (Blank and Dutton 2012; Hansard Society 2014; Margetts 2011; Pattie et al. 2004; Stromer-Galley and Foot 2002).

In this context the Internet and on-line communication present both opportunities and challenges for how politicians communicate with the electorate (Coleman and Blumler 2009; Coleman and Shane 2011; Dahlberg 2011; Davis 2010; Enli and Skogerbø 2013; Gibson 2013; Hermans and Vergeer 2013; Jackson 2004; Karpf 2012; Larsson 2014; Lee 2014; Lilleker 2014; Lilleker and Jackson 2010; Lilleker et al. 2011; Lilleker et al. 2015; Strandberg 2013; Vergeer 2013; Vergeer et al. 2013a, 2013b; Ward et al. 2008). Tools such as email, blogs, on-line deliberation, forums, party selection tools and Twitter have the potential to bring politicians and the electorate into direct contact, and provide new opportunities for engagement and accountability. Politicians can communicate using the Internet in a personalized way, which goes beyond the controlled communication of, for example, a set piece speech or press release, and so they can build on relationships and connections built up via door-to-door and telephone campaigning. An integrated off- and online personalized approach to campaigning using digital media such as text messages and email is thought to have increased in recent USA presidential elections. For example, in 2012 some of the electorate were reportedly being sent daily emails (Bimber 2014; Smith and 
Rainie; 2008; Smith and Rainie 2008; Vaccari 2013). ${ }^{1}$ In the 2010 UK General Election, Southern and Ward (2011) found that 86 per cent of candidates had some form of website. Moreover social media communication is thought to have been crucial to campaigning in the 2013 Italian general election, particularly as used by Beppe Grillo and in the German general election as used by the Pirate Party (Bartlett et al. 2014). A further aspect of the innovations in communication and engagement is the potential of the Internet for electoral candidates from minor political parties and independent candidates who often have limited resources. This, in part, may be related not only to the potentially lower costs of such communication but also to issues of party control and the independence of candidates to engage with potential voters (Gibson and McAllister 2015; Margolis and Resnick 2000).

On-line campaigning has been shown to contribute to increased voter support, although this is debated (Boulianne 2009; Gibson and McAllister 2011; 2015; Green and Gerber 2004; Krueger 2002; Malhotra et al. 2012; Nickerson 2007; Nielsen 2011; Norris and Curtice 2008). The electorate is increasingly using the Internet as a source of political information (Smith and Duggan 2012). In 2010, Gibson and Cantijoch's (2011) survey of UK adults found that 16 per cent had visited official election campaign websites. However, evidence suggests that it is those voters who are already interested in politics who are making the most of the Internet as a tool for involvement whilst the wider population are disconnected (Davis 2010; Gibson et al. 2012; Lilleker and Jackson 2013; Norris 2003; Vaccari and Valeriani 2015). There are still gaps in Internet access and use, for example, in the UK and this digital divide is particularly apparent for those aged over 65 and those on lower incomes (ONS 2013).

There is only limited research directly examining the use of email and email content for political communication and electoral campaigning and what actually happens in practice. Jackson (2004) conducted a number of qualitative interviews with both Members of Parliament (MPs) and constituents in the UK about the use of email and its role in the MP constituency link and concluded that there was value in terms of building links between an elected representative and a constituent, but that it was dependent on the quality of the communications sent. There is also some limited evidence that email may have been opening up political communications to new sections of the electorate, especially younger professionals who 'would not have contemplated writing a letter' (Jackson 2005:100). Nielsen (2011) has argued that email communication is integral to political campaigns. Thomas Gensemer, who managed the Obama 2008 Presidential campaign, has suggested email had an instrumental role. He commented, 'For all the talk of social media...email is still the killer app. Our email list...was the backbone of our campaign' (Townsend 2009: 1). However research by Fisher et al. (2011) suggests that in the UK whilst candidate websites were increasingly being invested in, other on-line campaigning techniques such as email were only being used to a limited extent compared with more traditional leaflet and doorstep campaigning. It is notable that the party leaders sent campaign emails to their associate lists on the morning of the election as a culmination of an ongoing national email strategy (McGregor 2012). Yet evidence from the 2010 British Election Study (BES 2010) in the UK suggests that less than 15 per cent of respondents reported receiving emails from one of the major political parties, though this was comparable with contact rates via telephone. Recent research by Vaccari (2014) has found that across a number of European countries only around a third of political parties and electoral candidates responded to emails about policy issues (see Cogburn and Espinoza-Vasquez (2011), Katz et al. (2013) and Lilleker et al. (2015)).

Our focus in this article is on how politicians respond to the electorate and the nature of the direct interaction in practice via email. Using an innovative email study we consider how responsive politicians are and what might explain any differences in response rates and the types of response. More specifically, we consider the following questions: Are electoral 
candidates contactable via email? To what extent do electoral candidates respond to the electorate? What factors are associated with the likelihood of responding? Are electoral candidates providing relevant information to inform voter choice in their responses? To what extent are electoral candidates building direct, personal and two-way relationships with the electorate and renewing the representation interface?

\section{A Theoretical Framework for Representation, Communication and Responsiveness}

In the context of the digital society, Coleman (2005a) has outlined a typology representation. This includes: closeness and mutuality in the sense of citizens being connected to representatives and this being a two-way relationship which might involve sharing views and information; coherence in the sense of explaining decisions and policy, bringing together different views; and empathy in the sense of knowledge of and respect for the views and experiences of others. We can also draw on Eulau and Karps' (1977) research which identified different forms of responsiveness: policy responsiveness (where there is a congruence between the views of the electorate and the representative's views); service responsiveness (where the representative is involved in case work on behalf of individuals in their constituency); allocation responsiveness (where the representative seeks to secure resources on behalf of their constituency); and symbolic responsiveness (where the representative is in contact with the electorate and builds a direct relationship). At the heart of these issues is the relationship between citizens and politicians. In part this links to Habermas's (1989) discussion of the public sphere and the importance of critical dialogue and Dryzek's (2002) discussion of deliberative democracy. There is also a link to Dahlberg's (2011) theoretical framework of digital democracy and how deliberation can be supported through digital communication tools, in particular the importance of two-way communication as part of transparent, accountable and more direct governance.

Although the decline in citizen engagement has been subject to some debate (Hall 1999; Norris 2002; 2011) a number of key measures point to a disconnection between citizens and politicians in many advanced democracies (European Parliament 2014; Putnam 2000; Hansard Society 2014). For example, in the UK it has been argued that the electorate no longer votes simply out of duty or habit (Curtice et al. 2010; Pattie et al. 2004). Evidence from the 2014 British Social Attitudes Survey suggests only 17 per cent of people trust British governments to put the interests of the nation above those of their own political party (Ormston and Curtice 2014), compared to 47 per cent of people in 1987. In 201446 per cent of people felt that: 'Most politicians are in politics only for what they can get out of it personally'.

A lack of communication and connection between the electorate and politicians has been seen as a key factor in declining civic engagement. The UK Electoral Commission (2001) argued that the decreasing level of voter turnout is not about 'declining interest in politics or elections but rather of the failure of the campaign to connect with the electorate'. Research by Coleman (2005b) found that 72 per cent of people reported feeling 'disconnected' from the UK Parliament, very few members of the electorate felt connected to their local MP and many had a sense that elected representatives did not care about their views. It is notable that in the UK MPs undertake their roles in different ways and do not have a defined job description (Wright 2010). Research by Vivyan and Wagner (2015) has highlighted how the electorate wants MPs to be predominantly focused on constituency issues. Moreover one MP has argued that politicians should be subject to greater scrutiny including mystery-shopping checks as part of quality assurance measures (Danczuk 2014).

Evidence suggests that there are incentives for politicians to be responsive and in more direct contact with the electorate. The electoral benefits of localized and personalized campaigning at the constituency level have been widely documented as political campaigning 
has become more professionalized (Fieldhouse and Cutts 2008; Fisher and Denver 2008). Research by Johnston et al. (2012) has highlighted that the more ways in which people are contacted by a political party the more likely they are to vote for it. In the USA Griffin and Keane (2006) found that for certain groups, participation in politics increased when their elected representatives were viewed as being responsive. A further aspect of this is the extent to which, through direct communication, politicians can build more personal relationships with the electorate based on their identity. For example, men and women have been shown to demonstrate different communication styles including using different levels of engagement and expression (Meyers-Levy and Loken 2014; Weiser 2000).

\section{Methods and data}

The methodology was designed to simulate real world conditions and provide a robust measure of responsiveness that might not be captured through a self-reported study (see Margetts (2011) for discussion of experimental approaches in social science).

An email was sent to a sample of 775 candidates during the first week of a UK general election campaign. The email, written by a hypothetical voter in an informal style, explained that the sender had not yet decided how to vote and requested information on the candidate's and the party's policy and what they planned to do about the issue of 'employment opportunities for graduates'. These were salient electoral issues and were thought to be something that all politicians and political parties would have a view on. On ethical grounds we also did not want to impose too much of a burden on the responding electoral candidates by asking about something requiring extensive work. This was crucial given the research evidence on how political parties and electoral candidates may target resources during an election. The email was non-specific in terms of the elector's constituency so the likelihood of an electoral candidate dismissing the email as not relevant was minimized. All the emails were sent within the first week of the election campaign. The full email text is included in the Appendix.

\subsection{Ethics}

The research was formally approved through the University's Research Ethics Committee (UREC). Elements of the methodology were covert in the sense that the research project was not disclosed to the participants. Whilst covert and unobtrusive research methods pose ethical challenges (Herrera 1999) they are well established in political and social science and approved by leading research councils and professional associations such as the British Sociological Association (BSA 2002), the Economic and Social Research Council (ESRC 2010) and the Social Research Association (SRA 2003). Covert and unobtrusive research methods have been used in a wide range of studies including in the area of civic engagement (e.g., Butler et al. 2012 and Vaccari 2014). Researchers such as Calvey (2008), Page (2000), Spicker (2011) and Webb et al. (1999) have made the case for covert and unobtrusive research in certain circumstances - where there is minimal or no harm to the participants and where awareness of the study would render the data of little value. These conditions were satisfied in the present study. There was no harm to the participants beyond the actual time taken to reply to the email.

Researching the actual behaviour of politicians in practice would be much more limited and subject to considerable measurement error if, for example, politicians were simply asked about their engagement with the electorate. We sought to minimize any potential harm the study may cause including the burden placed on the electoral candidates by asking a straightforward question. All the candidates' responses were anonymized. No personal or sensitive information about the individuals has been published. We committed to 
circulating a brief research summary once it was published to those who participated in the study and through practitioner networks more widely.

\subsection{Sample}

A sample of specifically defined 'marginal' constituencies was selected as a means of examining candidates' responsiveness in highly competitive contexts and to capture campaign activity in closely fought elections. Marginality was defined as constituencies that required a swing of up to 12 per cent to unseat the incumbent rather than the more usual 10 per cent. This was to ensure a large sample and was appropriate given the closeness of the election campaign. Labour Party marginal constituencies with a Conservative Party candidate in second place, which needed only a 5 per cent swing to unseat the incumbent were not included as these were unlikely to be Labour target seats. Of course not all marginal constituencies are the same. When targeting seats, political parties tend to limit campaign resources and spending where victory is unlikely (Whitely and Seyd 2003). The marginality criterion resulted in a sample of 775 candidates in a total of 172 marginal constituencies in England. 13 candidates were only contactable via website form and so were not included in the response phase as a standard email was being sent to all candidates. There were 572 male candidates and 190 female candidates in the sample. The political party breakdown was as follows: British National Party (BNP) 27, Green Party 86, Conservative Party 173, Labour Party 170, Liberal Democrat Party 169, and United Kingdom Independence Party (UKIP) 137. 641 candidates were challengers and 121 were incumbents.

The candidates' email addresses were gathered from on-line searches, which were beyond what might be reasonably expected of a member of the electorate when looking for a candidate's email address.

\subsection{Variables}

The key variables used in the analysis are summarised in the table below.

$<<$ Table 1 about here $>>$

\subsection{Limitations}

Covert-based approaches have limitations including the issue of detection. We limited this as much as possible in the research design. Only one electoral candidate contacted the undecided voter to ask if the email was part of a research project. We were only focused on a simple measure of responsiveness, however given this is one of the first studies of its kind in the UK this was an important first step in developing our understanding of the nature of direct communication and the representation interface.

\subsection{Follow-up Interviews}

A series of follow-up case study interviews were conducted with three electoral candidates from the major political parties. The issues of Internet campaigning, email use and communication strategies were discussed including in relation to the risks posed to politicians of going 'on record'.

\section{Findings}

\subsection{Do politicians respond to emails from the electorate?}


In order to examine how easy it is to contact politicians we first consider the availability of email addresses. Of the 775 candidates in our sample, 82 per cent had an email address that could be identified or had on-line contact forms via a website. Table 2 provides a summary of the electoral candidates' email addresses and type.

$<<$ Table 2 about here $>>$

Arguably the number of identifiable email addresses is suggestive of a high level of use of email as a form of communication amongst electoral candidates. However the sample is composed of candidates in marginal constituencies who might, given the competitiveness of the election in these constituencies, be considered to be more likely to be using email.

There were considerable differences in the number of usable email addresses identified and address type by candidates' political party, as summarized in Table 3.

\section{$<<$ Table 3 about here $>>$}

Amongst the three major political parties in our sample Liberal Democrat Party candidates were the most likely to have some form of an identifiable email address and the most likely to have an individual name email address. Candidates from the UKIP were the least likely to have an identifiable email address. BNP candidates were by far the most likely to have constituency office and regional party email addresses perhaps highlighting issues of party control, organization and resources. Of course even a candidate's individual email address can be answered on their behalf by support staff or central party office.

In terms of other key factors, incumbent candidates were more likely than challengers to have some form of identifiable email address ( 90 per cent compared with 80 per cent) and also more likely to have a candidate name as an email address ( 78 per cent compared with 62 per cent). This may reflect incumbent candidates' longer standing in their role and having built up their communication tools whilst in office. Suggesting an issue of cost and resources, 93 per cent of candidates with a higher campaign spend had an email address compared with 67 per cent of candidates with lower reported spends. Candidates with higher campaign spends were also much more likely to have an individual candidate name email address than those with lower spends ( 82 per cent compared with 43 per cent). Looking at the issue of campaigning, those who in terms of previous vote share were in a very competitive election and had a very good chance of winning their seat were more likely to have an email address compared with those candidates with large majorities or with no real chance of winning the seat (93 per cent compared with 68 per cent) and were also more likely to have an individual candidate name email address (80 per cent compared with 51 per cent).

In terms of responsiveness 373 email replies were received (49 per cent of the sample of 762 candidates). ${ }^{2}$ This amounts to 60 per cent of the sub-sample of 620 candidates where an apparently working email address was identified. 4 per cent of emails were returned as undeliverable. As Table 4 highlights, there was a relatively consistent pattern of response rate across the major political parties.

$<<$ Table 4 about here $>>$

The response rate from Green Party electoral candidates was comparable to that from the other major political parties, however candidates from the BNP and UKIP were the least likely to respond. In terms of other key factors, incumbent candidates were more likely to respond than challenger candidates ( 75 per cent compared with 60 per cent). Those candidates who in terms of previous vote share were in a very competitive election and had a 
very good chance of winning the seat were much more likely to respond than those who had large majorities or had little chance of winning the election (70 per cent compared with 40 per cent). It is notable that male electoral candidates were much more likely to respond than female candidates (64 per cent compared with 41 per cent). Interestingly there was little difference in terms of campaign spend.

We used logistic regression modelling to examine the likelihood of the electoral candidates responding to the elector's email. We considered the candidates' gender, political party, relative campaign spend, incumbency and individual marginality.

$$
<<\text { Table } 5 \text { about here }>>
$$

As shown in Table 5, very few of the associations are statistically significant and as such what we can learn more generally from the model is limited. However, given our focus on the nature of responsiveness amongst candidates in the sample of marginal constituencies at this particular election the findings are informative. We see that of the major political parties Labour Party candidates were the least likely to respond to the undecided voter. Of the minor political parties only Green Party candidates were more likely to respond than Labour Party candidates. Those electoral candidates with a relatively higher campaign spend were also more likely to respond. Male candidates were more likely to respond than female candidates in the sample. The associations between the likelihood of responding and incumbency and the candidates' marginality were statistically significant. Incumbent candidates were more likely to respond than challenger candidates and those candidates with a possible chance of winning the seat were also more likely to respond. As we discuss below, this in part may be an indication of the campaign-orientated approach to communication rather than one related to the representation interface and two-way communication.

Overall, the model only explains a limited amount of the variation in the likelihood of an electoral candidate responding, suggesting that there are other factors at work perhaps specific to on-line communication and how it is valued. This might include the way in which individuals view communication and their skills and experience in using the different tools, as has been highlighted by Marcinowski et al. (2014). In part this may be linked with how candidates individually decide to prioritize their campaigns and the work of their offices and campaign teams. The age of candidates may also be a factor given the well-established differences in the use of the Internet by age (Ofcom 2014). However, we were not able to capture this in our analysis. We consider these issues further in our discussions below.

A key aspect of the use of digital communication is the possibility of a rapid response. Of the 373 candidates who replied, 33 per cent replied the same day. Overall most candidates replied within three days. There was only limited use of holding or automated reply emails. Only 4 per cent of candidates had set up an auto-response email. As Table 6 highlights, there were some notable differences in response time by candidates' political party.

$<<$ Table 6 about here $>>$

Liberal Democrat Party candidates were the slowest to respond with over a quarter (28 per cent) of replies taking more than three days. Challenger candidates were quicker to respond than incumbent candidates, though the rates were comparable in terms of having replied within three days. Of course, response times might relate to the candidate's resources, the prioritization of email communication and also to how communication is managed and internal approval processes.

Personalization is also an important feature of digital communication particularly compared to more broadcast-based approaches to communicating. Overall, 90 per cent of the electoral candidates who replied used the elector's name in their email response. This 
represents a high level of personalization. The proportion of candidates using the elector's name was fairly consistent across different political parties. Personalization also extended to some of the electoral candidates referring to their own lives and experiences in their email replies. One electoral candidate wrote, 'Hi some years ago I too was a student at $\mathrm{xxxxx}$ University!' Another candidate wrote, 'As a former Tutor at xxxxx University I feel I am well-placed to understand the very real concerns students like you have'. Whilst another wrote, 'I have a lot of sympathy with your plight. My own daughter graduated last summer and still has not been able to find a permanent job or one commensurate with her skills'.

\subsection{How relevant is the content of politicians' emails?}

Responding is of course more than just replying; the content of communication is an important aspect of political engagement. The content of each email response was coded as to whether the issue raised by the undecided voter was answered directly. This was an important quality criterion in terms of understanding how candidates were communicating and engaging in a direct way with the electorate. The email responses from the candidates were analysed and coded in terms of: (1) 'Specific' - email answered the question directly; (2) 'Related' - email offered related information to the question; (3) 'General' - email made little or no mention of the specific question but just general campaigning information; or (4) Address clarification request - candidate asked for constituency address before providing further information. ${ }^{3}$ As Table 7 highlights, the content analysis revealed that only just over a quarter of candidates provided a Category 1 'Specific' answer.

$<<$ Table 7 about here $>>$

We now focus on exploring differences by political party and on the sub-sample of the 296 candidates who sent a response related to the question raised and exclude those 77 candidates who requested clarification of the elector's home address. As shown in Table 8, overall Labour Party candidates were the most likely to provide Category 1 'Specific' content in their email replies. Candidates from minor political parties, particularly from the UKIP and the BNP, were much less likely to give Category 1 'Specific' content replies.

$<<$ Table 8 about here $>>$

Challenger candidates were more likely to send a Category 1 'Specific' email reply compared with incumbent candidates (46 per cent compared with 32 per cent). In terms of campaign spending, those with relatively higher spends were more likely to provide a Category 1 'Specific' content email reply compared with candidates with relatively lower spends (48 per cent compared with 16 per cent). Those candidates who in terms of previous vote share were in a very competitive election and had a very good chance of winning their seat were more likely to provide a Category 1 'Specific' content email response compared with candidates with large majorities or with no real chance of winning (49 per cent compared with 21 per cent). In terms of gender, female candidates were much more likely to send a Category 1 'Specific' content email (56 per cent compared with 27 per cent).

In terms of the detailed content of the responses, Category 1 'Specific' responses often included reference to the party's track record and specific policies for creating jobs for graduates. For example, one candidate described their party's commitment to additional funding for postgraduates, volunteering, entrepreneurship places for graduates and support for business start-ups. Many candidates also added a sense of frustration with the system and empathy with the undecided voter. For example, as one respondent commented: 'I understand the concerns which you and your friends may have about employment opportunities for 
graduates. I fully believe that young people have a right to know that there will be opportunities for them when they complete their studies.' Another candidate commented in relation to job creation initiatives for graduates that: 'We have done a lot already, but there is definitely scope for more'.

The other categories were 'Related' in content or were 'General' campaigning responses, which did not include specific reference to the issue of 'graduate employment'. For example, one candidate referred to the economy in general and the need to nationalize certain industries. These kind of responses also often included issues that the candidate was concerned about and linked them to employment rather than graduate employment directly. As one candidate stated: "We would employ hundreds more teachers as part of our commitment to reduce class sizes to 20 . We would need more lawyers to work with asylum claimants and more front line social workers.' Another candidate claimed that their party was the most focused on graduates but did not provide information on employment opportunities. The candidate commented: 'Our policies are more beneficial to students than any other political party.' Those candidates who sent general campaigning responses did not address the issue raised by the voter but were more about stating what the party would do in general and often included a comment about which political party was responsible for the present economic problems. As one candidate wrote: 'Well who set up the regulatory system for banks then? Gordon Brown in 1997. The man who has consistently been spending more than he raised in taxes since becoming chancellor.' Another candidate commented: 'As you probably know, UKIP maintains that as a country we should return to governing ourselves, ruled by our own elected representatives from Westminster and not by the unelected and bureaucratic European Union'.

It is notable that overall 30 per cent of the candidates' email responses included an offer to provide further information. However it is perhaps striking that only six subsequent emails were received by the undecided voter. This suggests that in general the elector's details, contact information and political concerns had not been added to the candidates' campaign databases as part of a wider communication strategy. Five of the emails that were received came on, or around, the day of the election and all of them were standardized messages encouraging the person to vote. One other electoral candidate in the sample added the elector's email address to a regular mailing list, and a monthly newsletter was received from this candidate.

\subsection{Why are some politicians reluctant to communicate directly via email?}

One aspect of email communication and other on-line communication is the issue of the information being documented with the potential to be circulated beyond the intended recipient. This was identified in the case study follow-up interviews conducted with electoral candidates where it was suggested that there was a sense of being 'on record' when using email communications and hence candidates were often very careful when using email and were reluctant to get into detailed discussion.

One electoral candidate commented: 'I am very cautious of going off message via email or social media. A slip up can be distributed far and wide before you know it....and it is written proof. It would affect other candidates in [my party] potentially.... think it best to stick to quoting relevant party policy and being supportive. I wouldn't want to embarrass my party'. However, another candidate commented, whilst also highlighting a degree of caution with email communication, that they do attempt more direct engagement. They stated that whilst they often send standard email replies they 'give a little more of [their] own opinions and specific policy' when responding to emails from individuals. 


\section{Discussion and conclusions}

For an effective democracy politicians need to engage with the electorate, explain policy positions and have an ongoing understanding of citizens' concerns. Democratic systems and individual politicians have an increasing number of tools available to communicate and engage with the electorate. Email communication in particular has the scope, not only for broadcast communication, but also for individualized and personal communication. It can provide direct access to individual views and can be used for two-way discussion and deliberation to enhance democracy and drive forward engagement across the public sphere.

Direct contact between politicians and the electorate is associated with increased levels of civic engagement (Johnston et al. 2012). Not responding to the electorate is likely to have negative consequences, as the citizen contacting the politician does not know if his or her communication was ever received or read. This potentially undermines the citizen's sense of efficacy and perception of the legitimacy of the politician's role. Returning to Eulau and Karps' (1977) different forms of responsiveness, whether in terms of policy responsiveness, service responsiveness, allocation responsiveness or symbolic responsiveness, it is clear that it is only through communication that politicians can ensure they are acting as representatives.

The unique data from our study suggests that the digital tools available to politicians and specifically email are only being used in a limited way. As such, Coleman's (2005a) idea of connected representation is only partially realized. The overall email response rates from the electoral candidates in our sample fall below the performance agreements of many public service and private sector customer service standards in the UK, although such organizations are likely to have considerably more resources than electoral candidates. But this is particularly of concern as our sample was based on marginal constituencies where electoral competition was likely to be high. The vast majority of candidates who replied to the email did so within three days suggesting evidence of effective use of the immediacy of email communication. There was also a high level of personalization in the candidates' email replies, though of course emails can be written on behalf of candidates and via some form of centrally managed communication process. However whilst communication is about replying, it is also about recognition of the content of the message. As our email content analysis revealed, only just over a quarter of electoral candidates provided a Category 1 'Specific' answer.

In terms of identifying the drivers of responsiveness, on the whole in our sample of electoral candidates, apart from Green Party candidates, those from the major political parties were more likely to respond to the elector's email than those from minor political parties, suggesting that the balance of power and resources are largely being reproduced on-line, as has been highlighted by other research (Margolis and Resnick 2000). The differences in response rates by political party are likely to be related to a number of factors including resources, electoral priorities, technical expertise and the culture of political control within a party. Gibson and Rommele (2001) have observed that Green parties especially favour webbased communications and it has been suggested this may be because they are inherently more 'open' and less centralized in their ethos. The lower levels of identifiable email addresses, responsiveness and limited relevance of responses from the UKIP and BNP candidates suggest a lack of engagement with the electorate and perhaps also more centralized party control. It is clear that this can be seen as a missed opportunity to engage directly with the electorate amongst candidates standing for smaller parties. As outlined, such opportunities involving the use of the Internet and social media tools have recently been exploited by newer parties such as the Pirate parties across Europe and Beppe Grillo in Italy (Bartlett et al. 2014). It is notable that Gibson and McAllister (2015) have also pointed to the 
Internet as providing some rebalancing of the competition and resources between major and minor parties.

In terms of other interrelated factors, those candidates who had a relatively higher campaign spend, who were incumbent and who in terms of previous vote share were in a competitive election with a reasonable chance of winning were more likely to respond to the undecided voter's email. It is likely that resources are, in part, linked to incumbency in that the candidates in our sample of marginal constituencies have an established on-line identity and a more developed communication infrastructure. But it also suggests some evidence of adaptation amongst incumbent candidates to new ways of campaigning. Whilst there may be some cost savings when comparing email communication with posting leaflets, email communication is not cost free and can be resource intensive when done professionally. Moreover, in terms of building up an on-line presence and an email database of their potential supporters, this is likely to take some time and may require new skills. The UK's Electoral Commission (Author's communication) suggests there is still a lack of legal clarity about the extent to which existing on-line resources can be used during an election campaign.

Overall the direct observation data from our research suggests a broadcast-based approach to email communication similar to leaflet and television-based campaigning, perhaps linked to the concerns amongst politicians about being 'on record' and being cautious about giving detailed policy commitments when using email and the potential loss of control of the information. It may also relate to a lack of having a policy position amongst some electoral candidates and a desire to focus only on certain political issues. It could also be that, even in our sample of marginal constituencies, certain candidates were not that active in the campaign and were more just standing for election in name only. It is notable that research by Cardenal (2013) has found in Spain that larger, less ideological parties are more likely to use on-line mobilization strategies as they perceive the benefits to be substantial and the costs limited. The differences in terms of gender are revealing, including the extent to which women are less likely to respond overall, but when they do respond they are more likely to provide a relevant response. Different communication tools and modes may suit different types of candidates and personalities. Although the gender differences were not significant when other key factors were controlled for in the analysis, they are important in the context of our sample.

The limited explanatory power of the statistical model of responsiveness suggests that other factors might be linked with the use of email communication. As outlined above, there is some debate about the extent to which politicians value and are able to prioritize on-line communication (Gibson and McAllister 2015; Gibson and Cantijoch 2011; Lilleker and Jackson 2013; Marcinowski et al. 2014; Nielsen and Vaccari 2013; Vaccari 2014). In part this may be an issue of the skills and experience of the candidates and their campaign teams and their personal campaign priorities, as has been highlighted by McGregor at the national level (2012) and also by Graham et al. (2014) in relation to politicians' use of Twitter. The age of the politicians may also be a factor, given the well-established differences in the use of the Internet by age (Ofcom 2014); however, we were not able to capture this in our analysis and so it is clearly an area for further research.

It is clear that any communication activity has a resource cost and, despite email being low cost on one level, the management of communication and the time resources of responding are likely to be considerable. Politicians may feel more confident in using what they see as proven campaign tools including prioritizing communication with known supporters. In addition, electoral candidates and their party offices may be overwhelmed by the number of emails they receive from the electorate and other campaign organizations. For example, research in the USA has suggested that even more than a decade ago senators were being sent as many as 55,000 emails a month (Fitch and Goldschmidt 2005). Whilst in 2011 some MPs in the UK reported receiving up to 200 emails a day, many from campaign groups 
(Halfon 2011; Jackson 2004). An MP in the UK has reportedly threatened to complain to the Information Commissioner about the use of his email address and the volume of emails he was being sent (Pidd 2010). Of course email management systems - including junk mail filters, holding emails, mailing lists and newsletter briefings - could be put in place to reduce the time and resource costs involved in on-line communication. Many organizations have to manage large flows of email communications. The very small number of holding emails and follow-up emails received from the electoral candidates in our study and the very few requests to sign up to newsletter lists in order to build and maintain relationships during an election and in the longer term suggest only a limited use and integration of the tools available. This is clearly a missed opportunity to take candidates beyond just being reactive to requests from the electorate and to bridge the gap to a more direct relationship with the electorate.

It is notable that there is growing evidence to suggest that engaged and responsive email communication is desired by the electorate. The Oxford Internet Institute found that of those respondents they interviewed, 34 per cent had contacted a politician online (Dutton and Blank, 2012). It is clear that citizens are increasingly moving online in their communications with their representatives. At the 2010 UK general election, qualitative research by Lee (2013) suggested that a large amount of dialogue is occurring between politicians and the electorate over email. As Lilleker et al. (2015) have highlighted, there is a growing recognition of the importance of new media in professional political campaigning and evidence of the embedding of hypermedia campaigning amongst political parties in many European countries. Even so, a key focus of the use of the Internet by political parties has to date been on marketing rather than broader democratic engagement and dialogue beyond core supporters (Lilleker and Jackson 2013). Moreover, research by Nielsen and Vaccari (2013) has highlighted the limited public interest in the social media used by many politicians.

Citizen engagement and democratic transparency are not solely the responsibility of the citizen; they require a democratic system that fosters them. As Richards and Smith (2015) have argued, there is a need for a new openness and increased accountability amongst politicians. Moreover, evidence from the Audit of Democracy highlights how the public is keen to see new ways of holding politicians to account (Hansard Society 2014). The web tool TheyWorkForYou, developed by mySociety, is a hugely valuable resource for the scrutiny of MPs' activity, but it is notable that it was established by an organization external to Parliament, rather than being a formal performance audit.

There is a growing range of communication tools available to enable a more direct relationship between politicians and the electorate. Even if more resources may be required to ensure effective two-way communication, digital tools have the potential to transform the hierarchical model of political representation and to change the representation interface. New routes of information transmission, increased communication and dialogue give more scope for transparency and for politicians to explain their policy positions and decisions and to be informed about the concerns of the electorate. Such a change could lead to a more transparent democracy with increased scrutiny and accountability. We are not suggesting that direct communication and representation should be about congruence between the views of politicians and the electorate, but it is important that politicians are engaged and responsive.

\section{Acknowledgments}

We would like to acknowledge the time of the electoral candidates who participated in this study. We hope that they find the research and evidence useful in their own roles. 


\section{References}

Åström, J. and Karlsson, M. (2013). Blogging in the Shadow of Parties: Exploring Ideological Differences in Online Campaigning. Political Communication, 30, 3, pp. 434445.

Bartlett, J., Littler, M., McDonnell, D. and Froio, C. (2014). New political actors in Europe: Beppe Grillo and the M5S. London: Demos.

British Election Study (BES) (2010). British Election Study Campaign Internet Panel Survey. University of Essex.

Bimber, B. (2014). Digital Media in the Obama Campaigns of 2008 and 2012: Adaptation to the Personalized Political Communication Environment. Journal of Information Technology and Politics, 11, 2, pp. 130-150.

Blank, G. and Dutton, W. H. (2012). Age and Trust in the Internet: The Centrality of Experience and Attitudes Toward Technology in Britain. Social Science Computer Review 30, 2 pp. 135-151.

Boulianne, S. (2009). Does Internet Use Affect Engagement? A Meta-Analysis of Research. Political Communication, 26, 2, pp. 193-211.

BSA (2002) Statement of Ethical Practice. London: British Sociological Association. Butler, D. M., Karpowitz, C.F and Pope, J.C. (2012) A Field Experiment on Legislators' Home Styles: Service Versus Policy. The Journal of Politics, 74 pp. 474-486.

Butler, D.M. and Broockman, D.E. (2011) Do Politicians Racially Discriminate Against Constituents? A Field Experiment on State Legislators. American Journal of Political Science 55,3 , pp. 463-477.

Calvey, D. (2008) The art and politics of covert research. Sociology 42 pp. 905-18.

Cardenal, A. S. (2013). Why mobilize support online? The paradox of party behaviour online. Party Politics, 19, 1, pp. 83-103.

Cogburn, D. L. and Espinoza-Vasquez, F. K. (2011). From networked nominee to networked nation: Examining the impact of Web 2.0 and social media on political participation and civic engagement in the 2008 Obama campaign. Journal of Political Marketing, 10, pp. 189-213.

Coleman, S. (2005a). New mediation and direct representation: reconceptualizing representation in the digital age. New Media and Society, 7,2, pp. 177-198.

Coleman, S. (2005b). The lonely citizen: indirect representation in an age of networks.

Political Communication, 22, 2, pp. 197-214.

Coleman, S. and Blumler, J. G. (2009). The Internet and Democratic Citizenship: Theory, Practice and Policy. Cambridge: Cambridge University Press.

Coleman, S. and Gotze, J. (2001). Bowling together: Online public engagement in policy deliberation. Hansard Society: London.

Coleman, S. and Shane, P. M. (Eds) (2011). Connecting Democracy, Boston, USA: MIT Press.

Crabtree, J. (2010). Cameron's Battle to Connect. Wired, March $7^{\text {th }} 2010$.

Curtice, J., Fisher, S. and Ford, R. (2010). The Results Analysed. In Cowley, P. and

Kavanagh, D. (Eds) The British General Election of 2010. London: Palgrave.

Dahlberg, L. (2011). Re-constructing digital democracy: an outline of four 'positions'. New

Media \& Society. 13, 6, pp. 855-872.

Danczuk, S. (2014). A new politics: Let's give MPs a job description. Fabian Society.

Comment.

Davis, A. (2010). New media and fat democracy: the paradox of online participation. New

Media \& Society. 12, 5, pp. 745-761.

Dryzek, J. (2002). Deliberative Democracy and Beyond: Liberals, Critics, Contestations.

Oxford: Oxford University Press. 
ESRC (2010) Framework for Research Ethics. Swindon: Economic and Social Research Council.

Electoral Commission (2001). Voter Engagement and Young People. London: Electoral

Commission.

Electoral Commission (2012). Party Finance. London: Electoral Commission.

Enli, G. S. and Skogerbø, E. (2013). Personalized Campaigns In Party-Centred Politics. Information, Communication \& Society. 16, 5, pp. 757-774.

Eulau, H. and Karps, P. D. (1977). The Puzzle of Representation: Specifying Components of Responsiveness. Legislative Studies Quarterly, 2, 3, pp. 233-254.

European Parliament (2014). Turnout at European Parliament Elections. Brussels: European Parliament.

Fieldhouse, E. and Cutts, D. (2008). The effectiveness of local party campaigns in 2005: combining evidence from campaign spending and agent survey data. British Journal of Political Science, 39, 2, pp. 367-388.

Fisher, J. and Denver, D. (2008). From foot-slogging to call centres and direct mail: a framework for analysing the development of district-level campaigning. European Journal of Political Research, 47, 6, pp. 794-826.

Fisher, J., Cutts, D. and Fieldhouse, E. (2011) Constituency campaigning in 2010. In Wring, D., Mortimore, R. and Atkinson, S. (Eds) Political Communication in Britain: TV Debates, the Media and the Election. Basingstoke: Palgrave.

Fitch, B. and Goldschmidt, K. (2005). Communicating with Congress: How Capitol Hill is Coping with the Surge in Citizen Advocacy. Washington, DC: Congressional Management Foundation.

Gibson, R. (2013). Party Change, Social Media and the Rise of 'Citizen-initiated' Campaigning. Party Politics, 1,1, pp. 1-15.

Gibson, R. and Cantijoch, M. (2011). Comparing Online Elections in Australia and the UK: Did 2010 Finally Produce 'The Internet Election'? Communication, Politics and Culture, 44, 2, pp. 4-17.

Gibson, R. K. and McAllister, I. (2011). Do online election campaigns win votes? The 2007 Australian YouTube election. Political Communication, 28, 2, pp. 227-244.

Gibson, R. K. and McAllister, I. (2015). Normalising or Equalising Party Competition? Assessing the Impact of the Web on Election Campaigning. Political Studies, 63, 3 pp. 529547.

Gibson, R. K. and Rommele, A. (2001). Changing Campaign Communications: A PartyCentered Theory of Professionalized Campaigning. The Harvard International Journal of Press/Politics, 6, 4, pp. 31-43.

Gibson, R.K., Williamson, A. and Ward, S. (Eds) (2012). The Internet and the 2010 Election - Putting the Small 'p' Back in Politics? London: Hansard Society.

Graham, T., Jackson, D. and Broersma, M. (2014). New platform, old habits? Candidates' use of Twitter during the 2010 British and Dutch general election campaigns. New Media \& Society pp. 1-19.

Green, D. P. and Gerber, A. S. (2004). Get out the vote! How to increase voter turnout. Washington, D.C.: Brookings Institution Press.

Griffin, J. D. and Keane, M. (2006). Descriptive Representation and the Composition of African American Turnout. American Journal of Political Science, 50, 4, pp. 998-1012. Habermas, J. (1989). The Structural Transformation of the Public Sphere, Cambridge: Polity Press.

Halfon, R. (2011). Want to successfully lobby your MP? Make it personal and make it local. Guardian Professional, $3^{\text {rd }}$ February 2011.

Hall, P. (1999). Social Capital in Britain. British Journal of Political Science, 29, 3, pp. $417-$ 461. 
Hansard Society (2014). Audit of Political Engagement: The 2014 Report. London: Hansard Society.

Hermans, L. and Vergeer, M. (2013). Personalization in e-campaigning: a cross-national comparison of personalization strategies used on candidate websites of 17 countries in EP elections 2009. New Media \& Society. 151, pp. 72-92.

Herrera, C. D. (1009) Two arguments for 'covert methods' in social research. The British Journal of Sociology. 50, 2 pp. 331-343.

Jackson, N. (2004). Email and political campaigning: the experience of MPs in Westminster. Journal of Systemics, Cybernetics and Informatics, 2, 5, pp. 1-6.

Jackson, N. A. (2005). Vote Winner or a Nuisance: Email and Elected Politicians' Relationship with Their Constituents. Journal of Nonprofit and Public Sector Marketing 14, 1-2, pp. 91-108.

Jackson, N. A. and Lilleker, D.G. (2009). Building an architecture of participation? Political parties and web 2.0 in Britain. Journal of Information Technology \& Politics 6, 3, pp. 232250 .

Johnston, R., Pattie, C., Cutts, D. and Fisher, J. (2012). 'Spending, contacting, and voting: the 2010 British general election in the constituencies', Environment and Planning A, 44, 5, pp. 1165-1184.

Johnston, R., Pattie, C., Fisher, J., Cutts, D. J. and Fieldhouse, E. (2013). 'The long and the short of it: local campaigning at the British 2010 General Election'. Political Studies, 61, pp. 114-137.

Karpf, D. (2012). The Move On Effect: The unexpected transformation of American political advocacy. New York, NY: Oxford University.

Katz, E. J., Barris, M. and Jain, A. (2013). The Social Media President: Barack Obama and the Politics of Digital Engagement. New York, Palgrave.

Krueger, B. (2002). Assessing the Potential of Internet Political Participation in the United States A Resource Approach. American Politics Research 305 pp. 476-498.

Larsson, A. O. (2014). Online, all the time? A quantitative assessment of the permanent campaign on Facebook. New Media \& Society pp. 1-19.

Lee, B. (2014). Window Dressing 2.0: Constituency-Level Web Campaigns in the 2010 UK General Election. Politics, 34, pp. 45-57.

Lilleker, D. G. (2014). Political communication and cognition. Basingstoke: Palgrave.

Lilleker, D. G. and Jackson, N. A. (2010). Towards a more participatory style of election campaigning: the impact of Web 2.0 on the UK 2010 general election. Policy and Internet, 2,3, pp. 67-96.

Lilleker, D., and Jackson, N. A. (2011). Political Campaigning, Elections and the Internet: Comparing the US, UK, France and Germany. London: Routledge.

Lilleker, D. G. and Jackson, N.A. (2013). Reaching Inward Not Outward: Marketing via the Internet at the UK 2010 General Election, Journal of Political Marketing, 12, 2, 3, pp. 244261.

Lilleker, D., Koc-Michalska, K., Schweitzer, E. J., Jacunski, M., Jackson, N. A. and Vedel, T. (2011). Informing, engaging, mobilizing or interacting: Searching for a European model of Web campaigning. European Journal of Communication, 26,3, pp. 195-213.

Lilleker, D.G., Tenscherbc, J. and Štětka, V. (2015). Towards hypermedia campaigning? Perceptions of new media's importance for campaigning by party strategists in comparative perspective. Information, Communication \& Society, 18, 7, pp. 747-765.

McGregor, M. (2012). The use of email in the 2010 Election. In Gibson, R.K., Williamson, A. and Ward, S. (Eds) The Internet and the 2010 Election - Putting the small 'p' back in politics? London: Hansard Society. pp. 33-42.

Malhotra, N., Michelson, M. R. and Valenzuela, A. A. (2012). Emails from official sources can increase turnout. Quarterly Journal of Political Science, 7, 3, pp. 321-332. 
Marcinowski, F., Metag, J. and Wattenberg, C. (2014). 'Why do candidates use online media in constituency campaigning? An application of the theory of planned behaviour'. Journal of Information Technology and Politics, 11, 2, pp. 151-168.

Margetts, H. Z. (2011). Experiments for Public Management Research. Public Management Review, 13, 2, pp. 189-208.

Margolis, M. and Resnick, D. (2000). Politics as Usual? The Cyberspace Revolution. London: Sage.

Meyers-Levy, J. and Loken, B. (2014). Revisiting gender differences: What we know and what lies ahead. Journal of Consumer Psychology 25,1, pp. 129-149.

Nickerson, D. W. (2007). Does email boost turnout?' Quarterly Journal of Political Science, 2,4, 369-379.

Nielsen, R. K. (2009). The labors of Internet-assisted activism: overcommunication, miscommunication, and communicative overload. Journal of Information Technology and Politics, 6, 3, 4, pp. 267-280.

Nielsen, R. K. (2011). Mundane Internet tools, mobilizing practices, and the coproduction of citizenship in political campaigns. New Media \& Society, 13, 5, pp. 755-771.

Nielsen, R. K. and Vaccari, C. (2013). Do people 'like' candidates on Facebook? Not really: Large-scale direct candidate-to-voter online communication as an outlier phenomenon. International Journal of Communication, 7, pp. 2333-2356.

Norris, P. (2002). Democratic Phoenix: Reinventing Political Activism. New York: Cambridge University Press.

Norris, P. (2003). Preaching to the converted? Pluralism, participation and party Websites. Party Politics, 9, 1, pp. 21-45.

Norris, P. (2011). Democratic deficit: Critical citizens revisited. New York, NY: Cambridge University Press.

Norris, P. and Curtice, J. (2008). Getting the Message Out: A two-step model of the role of the Internet in campaign communication flows during the 2005 British General Election. The Journal of Information Technology and Politics, 4, 4, pp. 3-13.

Ofcom (2014). The Communications Market Report. London: Ofcom.

ONS (2013). Internet Access Quarterly Update. London: Office for National Statistics.

Ormston, R. and Curtice, J. (2014). $32^{\text {nd }}$ British Social Attitudes Report. London: NatCen.

Page, S. (2000) Community research: The lost art of unobtrusive methods. Journal of Applied Social Psychology 30,10, pp. 2126-2136.

Pattie, C., Seyd, P. and Whitely, P. (2004). Citizenship in Britain, Values, Participation and

Democracy. Cambridge: Cambridge University Press.

Pidd, H. (2010). Conservative MP tried to remove email address from websites. The

Guardian, Monday 9th August 2010.

Pitkin, H. F. (1967). The Concept of Representation. Berkeley, CA: University of California Press.

Putnam, R. (2000). Bowling Alone. New York: Simon and Schuster.

Rallings, C. and Thrasher, M. (2008). Constituency Database [online]

http://election.pressassociation.com/constituencies.html

Richards, D. and Smith, M. J. (2015). In Defence of British Politics Against the British

Political Tradition. The Political Quarterly. 86, 1, pp. 41-51.

Russmann, U. (2011). Targeting voters via the Web-a comparative structural analysis of Austrian and German party web sites. Policy and Internet, 3, 3, pp. 1-23.

Smith, A. and Duggan, M. (2012). The State of the 2012 Election. Washington DC: Pew. Smith, A. and Rainie, L. (2008). The Internet and the 2008 election. Washington, DC: Pew Internet and American Life Project. 
Southern, R. and Ward, S. (2011). Below the Radar? Online Campaigning at the Local Level in the 2010 Election in Wring, D., Mortimore, R. and Atkinson, S. (Eds) Political communication in Britain. London: Palgrave Macmillan.

Spicker, P. (2011) Ethical Covert Research. Sociology 45, 2 pp. 118-133.

SRA (2003) Ethical Guidelines. London: Social Research Association.

Strandberg, K. (2013). A social media revolution or just a case of history repeating itself? The use of social media in the 2011 Finnish parliamentary elections. New Media \& Society, 15, pp. 1329-1347.

Stromer-Galley, J. and Foot, K. A. (2002). Citizen perceptions of online interactivity and implications for political campaign communication. Journal of Computer-Mediated

Communication, 8,1, pp. 1083-1090.

Townsend, J. (2009) Obama's digital guru at City: "Email is still the killer app". 19th February 2009. Accessed July 2013. http://blogs.journalism.co.uk/2009/02/19/obamasdigital-guru-aka-thomas-gensemer-at-city-email-is-still-the-killer-

app/\#sthash.84eWSJ2z.dpuf

Vaccari, C. (2013). A Tale of Two e-Parties: Candidate Websites in the 2008 US Presidential Primaries. Party Politics, 19, pp. 19-40.

Vaccari, C. (2014). You've Got (No) Mail: How Parties and Candidates Respond to E-mail Inquiries in Western Democracies. Journal of Information Technology and Politics, 11, pp. 245-258.

Vaccari, C. and Valeriani, A. (2015). Follow the leader! Direct and indirect flows of political communication during the 2013 Italian general election campaign. New Media \& Society. 17, pp. 1025-1042.

Vergeer, M. (2013). Politics, elections and online campaigning: Past, present and a peek into the future. New Media Society, 15, 1, pp. 9-17.

Vergeer, M., Hermans, L. and Sams, S. (2013a). Online social networks and micro-blogging in political campaigning: The exploration of a new campaign tool and a new campaign style. Party Politics, 19, 3, pp. 477-501.

Vergeer, M., Hermans, L., and Cunha, C. (2013b). Web campaigning in the 2009 European parliament elections: A cross-national comparative analysis. New Media \& Society, 15, pp. 128-148.

Vivyan, N. and Wagner, M. (2015). What Do Voters Want From Their Local MP? The Political Quarterly, 86, 1, pp. 33-40.

Ward, S., Owen, D., Davis, R., and Taras, D. (Eds). (2008). Making a difference: A comparative view of the role of the internet in election politics. Lanham: Lexington Books.

Webb, E.J., Campbell, D.T., Schwartz, R.D and Sechrest, L. (1999) Unobtrusive Measures. London, Sage.

Weiser, E. (2000). Gender differences in Internet use patterns and Internet application preferences: A two-sample comparison. Cyber Psychology and Behavior, 3, 2, pp. 167-178. Whitely, P. and Seyd, P. (2003). How to Win By a Landslide By Really Trying: The Effects of Local Campaigning on Voting in the 1997 British General Election. Electoral Studies, 22, 2, pp. 301-324.

Wright, T. (2010) What are MPs For? The Political Quarterly, 81, 3, pp. 298-308. 


\section{Appendix 1 - Email Text Sent To Electoral Candidates}

\section{Email Text}

"Hi there, I watched the leaders debate on TV the other night, I have to say that as a student I didn't really feel that any of the politicians up there addressed the question that me and most of my friends are really concerned about - employment opportunities for graduates.

There are a lot of stories in the media right now about how much debt students are facing to get good qualifications and how they are finding it really hard to find a job.

I would like to know more specifically what you and your party will do to help address these problems. I haven't decided who I am going to vote for yet!

Thanks

$X X X X X X$ 


\section{Tables}

\section{Table 1. Key Variable Coding}

\begin{tabular}{|l|l|}
\hline $\begin{array}{l}\text { Candidate's reported } \\
\text { campaign spend }\end{array}$ & $\begin{array}{l}\text { Low Spend } \leq £ 2,000 ; \text { Medium Spend }>£ 2,001-\leq £ 15,000 ; \text { High } \\
\text { Spend }>£ 15,000 \text { (Electoral Commission 2012). }\end{array}$ \\
\hline $\begin{array}{l}\text { Candidate's individual } \\
\text { marginality (within the } \\
\text { sample of marginal } \\
\text { constituencies) }\end{array}$ & $\begin{array}{l}\text { Winnable } \leq 10 \text { per cent swing; Possible }>10 \text { per cent }-\leq 20 \text { per cent } \\
\text { swing; Safe/Unwinnable }>20 \text { per cent swing (Rallings and Thrasher } \\
\text { 2008). There were: } 220 \text { candidates in Winnable positions in their } \\
\text { constituencies, 146 candidates in Possible winnable positions and } 396 \\
\text { candidates in Safe/Unwinnable positions. }\end{array}$ \\
\hline $\begin{array}{l}\text { Email response content } \\
\text { relevance }\end{array}$ & $\begin{array}{l}\text { The content of the electoral candidates email responses was coded as } \\
\text { outlined below in the results section in terms of (i) Specific; (ii) } \\
\text { Related; or (iii) General. The coding captured the content relevance of } \\
\text { the candidate's reply. To check for coding consistency a sample of the } \\
\text { email responses was blind coded by volunteers. }\end{array}$ \\
\hline
\end{tabular}


Table 2. Type of Email Address

\begin{tabular}{|l|c|c|}
\hline Type of Email Address & \% & N \\
\hline Individual candidates name email address & 65 & 502 \\
\hline Local constituency office email address & 9 & 72 \\
\hline Party secretary/office assistant email & 5 & 37 \\
\hline Regional party group email address & 1 & 9 \\
\hline Contact via website (form) & 2 & 13 \\
\hline No email address identified & 18 & 142 \\
\hline Total & $\mathbf{1 0 0}$ & $\mathbf{7 7 5}$ \\
\hline
\end{tabular}


Table 3. Type of Email Address by Candidates' Political Party

\begin{tabular}{|c|c|c|c|c|c|c|c|}
\hline Candidates Political Party & \begin{tabular}{|l}
$\%$ Individual \\
candidate \\
name email \\
address
\end{tabular} & $\begin{array}{l}\% \text { Local } \\
\text { constituency } \\
\text { office email } \\
\text { address }\end{array}$ & $\begin{array}{l}\text { \% Party } \\
\text { secretary/ } \\
\text { assistant email } \\
\text { address }\end{array}$ & $\begin{array}{l}\text { \% Regional } \\
\text { party office } \\
\text { email address } \\
\text { - (covering } \\
\text { more than one } \\
\text { constituency) }\end{array}$ & $\begin{array}{l}\% \text { Contact } \\
\text { via website } \\
\text { form }\end{array}$ & $\begin{array}{l}\% \text { No email } \\
\text { address } \\
\text { identified }\end{array}$ & Total N \\
\hline British National Party & 19 & 19 & 0 & 30 & 0 & 33 & 27 \\
\hline Conservative Party & 81 & 11 & 1 & 0 & 0 & 7 & 173 \\
\hline Green Party & 46 & 9 & 8 & 1 & 5 & 31 & 91 \\
\hline Labour Party & 75 & 5 & 5 & 0 & 1 & 15 & 171 \\
\hline Liberal Democrat Party & 84 & 9 & 6 & 0 & 1 & 1 & 170 \\
\hline UKIP & 31 & 11 & 7 & 0 & 4 & 47 & 143 \\
\hline Total & 65 & 9 & 5 & 1 & 2 & 18 & 775 \\
\hline
\end{tabular}

Note: The differences were statistically significant $\mathrm{P}=<0.000$ 
Table 4. Email Response by Candidates' Political Party

\begin{tabular}{|l|c|c|}
\hline Candidate's Political Party & \% Replied & $\mathrm{N}$ \\
\hline British National Party & 35 & 17 \\
\hline Conservative Party & 65 & 158 \\
\hline Green Party & 67 & 57 \\
\hline Labour Party & 62 & 138 \\
\hline Liberal Democrat Party & 65 & 161 \\
\hline UKIP & 55 & 66 \\
\hline Total & 62 & $597^{*}$ \\
\hline
\end{tabular}

* Total number excludes those candidates where no address could be found (142), those contactable only via an on-line form (13) and those emails that were returned undelivered (23). The differences were statistically significant $\mathrm{P}=<0.000$. 
Table 5. Factors Associated with Responding to Email

\begin{tabular}{|c|c|c|c|c|c|}
\hline & $\begin{array}{l}\text { Coefficient } \\
\text { and (ORs) }\end{array}$ & $\begin{array}{c}\text { Std } \\
\text { Err } \\
\text { or }\end{array}$ & P-value & \multicolumn{2}{|c|}{ 95\% CIs } \\
\hline \multicolumn{6}{|l|}{ Gender } \\
\hline \multicolumn{6}{|l|}{ Male } \\
\hline Female & $-0.23(0.78)$ & 0.20 & 0.24 & -0.64 & 0.16 \\
\hline \multicolumn{5}{|c|}{ Candidate's Political Party } & Labour \\
\hline BNP & $-1.01(0.36)$ & 0.58 & 0.09 & -2.15 & 0.13 \\
\hline Conservative Party & $0.01(1.01)$ & 0.26 & 0.96 & -0.50 & 0.52 \\
\hline Green Party & $0.31(1.35)$ & 0.39 & 0.44 & -0.46 & 1.07 \\
\hline Liberal Democrats & $0.15(1.17)$ & 0.25 & 0.54 & -0.34 & 0.65 \\
\hline UKIP & $-0.26(0.77)$ & 0.36 & 0.46 & -0.97 & 0.44 \\
\hline $\begin{array}{l}\text { Candidate's Relati } \\
\text { Campaign Spend ( } \\
\text { Commission, 2012) } \\
\text { Low Spend }\end{array}$ & & & & & \\
\hline Medium Spend & $-0.02(0.98)$ & 0.28 & 0.95 & -0.56 & 0.53 \\
\hline High Spend & $0.16(1.17)$ & 0.33 & 0.64 & -0.49 & 0.81 \\
\hline Winnable & \multicolumn{4}{|c|}{ Candidate's Marginality } & \\
\hline Possible & $-0.48(0.62)$ & 0.24 & 0.05 & -0.96 & -0.01 \\
\hline Safe/Unwinnable & $-0.13(0.88)$ & 0.30 & 0.66 & -0.71 & 0.45 \\
\hline \multicolumn{6}{|l|}{ Incumbency } \\
\hline \multicolumn{6}{|l|}{ Challenger } \\
\hline Incumbent & $0.58(1.78)$ & 0.27 & 0.03 & 0.06 & 1.10 \\
\hline Constant & 0.58 & 0.36 & 0.47 & -0.12 & 1.29 \\
\hline $\mathrm{N}$ & 597 & & & & \\
\hline Pseudo R2 & 0.03 & & & & \\
\hline
\end{tabular}

Note: The electoral candidates requesting address confirmation are included here. 
Table 6. Email Response Time by Candidates' Political Party

\begin{tabular}{|l|c|c|c|c|}
\hline Candidates Political Party & \% Same Day & \% 1-3 Days & $\%>3$ Days & $\mathrm{N}$ \\
\hline British National Party & 83 & 0 & 17 & 6 \\
\hline Conservative Party & 29 & 52 & 19 & 102 \\
\hline Green Party & 45 & 42 & 13 & 38 \\
\hline Labour Party & 30 & 50 & 20 & 86 \\
\hline Liberal Democrat Party & 29 & 44 & 28 & 105 \\
\hline UKIP & 39 & 56 & 6 & 36 \\
\hline Total & 33 & 48 & 19 & 373 \\
\hline
\end{tabular}

Note: The differences were statistically significant $\mathrm{P}=<0.000$. 
Table 7. Content Relevance of Email Responses

\begin{tabular}{|l|r|r|}
\hline Email Content Coding & $\%$ & \multicolumn{1}{|c|}{ Total } \\
\hline 1. Specific content & $27 \%$ & 100 \\
\hline 2. Related content & $42 \%$ & 156 \\
\hline 3. General campaigning content & $11 \%$ & 40 \\
\hline 4. Home address clarification request & $21 \%$ & 77 \\
\hline Total & $100 \%$ & 373 \\
\hline
\end{tabular}

Note: The differences were statistically significant $\mathrm{P}=<0.000$. 
Table 8. Email Content Relevance by Candidates' Political Party

\begin{tabular}{|l|c|c|c|c|}
\hline Candidates Political Party & $\begin{array}{c}\text { \% 1. } \\
\text { Specific } \\
\text { content }\end{array}$ & $\begin{array}{c}\text { \% 2. Related } \\
\text { content }\end{array}$ & $\begin{array}{c}\text { \% 3. General } \\
\text { campaigning } \\
\text { content }\end{array}$ & $\mathbf{N}$ \\
\hline British National Party & 0 & 83 & 17 & 6 \\
\hline Conservative Party & 41 & 45 & 14 & 66 \\
\hline Green Party & 11 & 69 & 20 & 35 \\
\hline Labour Party & 52 & 32 & 16 & 62 \\
\hline Liberal Democrat Party & 41 & 52 & 8 & 91 \\
\hline UKIP & 0 & 83 & 17 & 36 \\
\hline Total & 34 & 53 & 13 & 296 \\
\hline
\end{tabular}

Note: The differences were statistically significant $\mathrm{P}=<0.000$.

\section{Endnotes}

\footnotetext{
${ }^{1}$ In the UK, political parties in the run up to the 2010 General Election were reported as consulting the same communications agency as the Democrat Party campaign in the USA (Crabtree 2010). In 2014 the UK Labour Party appointed a leading campaign figure from President Obama's team to support their 2015 General Election campaign. ${ }^{2}$ Here we exclude those 13 electoral candidates who had on-line contact forms as opposed to email addresses as it was not possible to track these replies in detail.

${ }^{3}$ The Category 4 'Home address request' relates to email responses where the candidate asked for confirmation that the elector lived in their constituency.
} 